\title{
Effect of COVID-19 on Dupont based financial performance of three Nationalized Petroleum Companies in India
}

\author{
Mukund S ${ }^{\mathbf{1}}$, Dr.N. Arunsankar ${ }^{2}$ \\ Marian International Institute of Management, Kerala \\ mukund@miim.ac.in ${ }^{1}$,arunsankar@miim.ac.in2
}

\begin{abstract}
Every company has two major objectives in terms of profitability. i.e. Profit Maximization and Shareholders' Wealth Maximization. Ratio analysis is a good tool which fosters the utilization of company figures to make proper investment decision for various classes of investors and management for taking right decisions at right time. ROE (Return on Equity) comes into the picture in terms of measuring the wealth maximization. It is basically a composition of ROCE or Return on Capital Employed. American paint manufacturing company named DuPont invented DuPont model of ROE analysis. It basically talks about the key factors contributing the return on equity. It can be used to analyze the return in any industry. In this study, we studied the impact of COVID-19 pandemic in their financial performance using DuPont analysis of the three Nationalized Petroleum company including BPCL, HPCL \& Indian Oil Corporation.
\end{abstract}

Keywords: Du-Pont, Profitability, Net Profit, Return on Capital Employed (ROCE)

Return on Equity (ROE)

\section{Introduction}

The major answer to the question "Why a Firm exist?" could be answered in two parts. First, obviously profit maximization and the second, Shareholder wealth maximization. It should be noted that the companies make use of various forms of Long-term capital to finance the long-term obligations of the business. There are 4 major sources of capital which include: Equity Share Capital, Preference Share capital (Together known as shareholders' fund), Debentures and borrowed capital (collectively known as borrowed source of funds). A study is mandatory in terms of understanding what actually drives the return of the company. This question is answered by DuPont Analysis brought forward by the DuPont Corporation in 1920s. This study analyzes the return on equity of three nationalized petroleum companies using DuPont Model. This study focusses on the effect of consumption of petroleum products during the COVID-19 pandemic which resulted in serious financial crisis for the petroleum companies in India. The effect of the pandemic on the financial performance of the three companies using Dupont analysis is studied here.

\section{Review of Literature}

Financial Performance analysis is a mandatory requirement done before investing into a single stock or a group of stocks. There are different tools for financial analysis including Price Earnings Ratio, Dividend Per Share, Dividend Yield ratio etc. A study conducted by (Berghoff and Kustner, n.d.) measured the financial performance of selected automobile stocks using DuPont analysis and came to a conclusion that Net Profit ratio effects the DuPont figure at maximum. A group of studies have been conducted by (Doorasamy, 2016) to know the effect of financial performance of selected metal stocks by using DuPont ratio. 
Another study investigated about the DuPont analysis of selected companies and came to a conclusion that, firms with higher Return on Equity provided more returns to the investors due to cutting edge competitive advantage (Sarkar and Choudhary, 2018)

The DuPont model of RoE analysis is an accurate methodology to measure the key factors which drives a company's profitability. It is a ratio which enables the management to identify the relationship between key variables / matrix which are important in profit generation. DuPont model helps understanding how operational, investment \& financing decisions directly affects profitability in long term perspective (Melvin, Boehlje, Dobbins and Gray, 2004).

The method of analyzing RoE is depicted using operational efficiency, asset utilization \& financial leverage. The optimization of these three matrices defines how well the company is able to generate profit and wealth to its investors (Soliman, 2007).

A study by (Berghoff and Kustner, n.d.) using DuPont analysis identified the various factors of efficiency and profitability which impacted the investment decisions of Russian Oil-extracting companies. DuPont analysis also helps to predict the future value of a company using the numbers in a big picture.

\section{Objectives of the Study}

1. To evaluate ROE using DuPont Model

2. To analyze the Return on Equity of the 3 Nationalized Petroleum Companies

3. To suggest the profitability of those companies

4. To comment on the efficiency of those companies

\section{Data Analysis}

The study uses the following statistical tools to interpret the ROE:

i. Mean - To understand the characteristics of the entire data. The total value will be divided by number of years ( 5 in this case)

ii. Standard Deviation - It measures the absolute dispersion. If the value of standard deviation increases, it is an indication of less uniformity among the data and vice versa.

iii. Co-Efficient of Variation - This measures the relative measure of variation. If this value is high, the dataset tends to be less consistent and if the value is less, the items would be more consistent.

iv. Compounded Annual Growth Rate (CAGR) - It analyzes the average growth of an amount over a period of a time. It varies according to the industries and also get effected by external factors too.

\subsection{Tables}

Table 5.1.1 DuPont Analysis

\begin{tabular}{|l|l|l|l|}
\hline DuPont Analysis & $\begin{array}{l}\text { Hindustan } \\
\text { Petroleum }\end{array}$ & $\begin{array}{l}\text { Bharath } \\
\text { Petroleum }\end{array}$ & Indian Oil \\
\hline ROE & $11.6 \%$ & $12.6 \%$ & $8.74 \%$ \\
\hline Net Profit Ratio & $2.15 \%$ & $2.52 \%$ & $1.98 \%$ \\
\hline Asset Turnover Ratio & 2.59 & 2.77 & 2.21 \\
\hline $\begin{array}{l}\text { Total assets to shareholders fund } \\
\text { ratio }\end{array}$ & 2.084 & 1.805 & 1.997 \\
\hline
\end{tabular}

Source: Annual Reports by Researcher (Money Control: Dion Global Solutions Limited) [Study Period from 2016 to 2020] 
The table clearly shows that the Return on Equity is highest for Bharath Petroleum. The main factor inducing these levels include a higher Net Profit Ratio \& Total asset to shareholders fund ratio. IOC being standing at the end when it comes to ROE. Generation of returns to the shareholders will be higher for BPCL compared to HPCL \& IOC. The effect of increased ROE suggests that the companies will also pay more dividend. BPCL is able to pay a higher interim as well as Final dividend to its shareholders. Even though the COVID-19 pandemic had put a stress in the individual indicators of the financial performance of these companies, the ROE seems to be pretty good and would outperform when unlock process is focused due to demand catching up.

Table 5.1.2 Sales

\begin{tabular}{|l|l|l|l|l|}
\hline Companies & $\begin{array}{l}\text { Average } \\
\text { Sales } \\
\text { (Rs. Lakhs) }\end{array}$ & $\begin{array}{l}\text { Standard } \\
\text { Deviation }\end{array}$ & $\begin{array}{l}\text { Coefficient } \\
\text { of Variation }\end{array}$ & CAGR \\
\hline $\begin{array}{l}\text { Hindustan } \\
\text { Petroleum }\end{array}$ & $2,25,621$ & $12.6 \%$ & $8.74 \%$ & $5.8 \%$ \\
\hline Bharath Petroleum & $2,41,552$ & $2.52 \%$ & $1.98 \%$ & $-3.25 \%$ \\
\hline Indian Oil & $4,27,087$ & 2.77 & 2.21 & $-6.59 \%$ \\
\hline
\end{tabular}

It is to be noted that the sales value for all the three companies were consistent in the years 2016, 2017, $2018 \& 2019$. But during 2020, the sale nosedived more than $60 \%$ for all the three companies due to nationwide lock down from March 2020. Since then the consumption for diesel and petrol plummeted. The average sales data of the companies for a period of five years is depicted above. It is evident that the Compounded Annual Growth Rate of Hindustan Petroleum is positive at $5.8 \%$ which is reflected even the sales value is comparatively lower than its peers. Bharath Petroleum and Indian Oil has provided negative growth rate for the past 5 years. But the growth cannot be believed since the standard deviation is very high for BPCL. It is more than 10 percent which shows the instability in terms of sales.

Table 5.1.3 - Net Profit

\begin{tabular}{|c|c|c|c|c|}
\hline \multirow{2}{*}{ Petroleum Companies } & \multirow{2}{*}{\begin{tabular}{|l|} 
Avg. Net \\
Profit (Rs. \\
Lakhs)
\end{tabular}} & \multirow{2}{*}{$\begin{array}{l}\text { Standard } \\
\text { Deviation }\end{array}$} & \multicolumn{2}{|c|}{ Coefficient of CAGR } \\
\hline & & & Variation & \%) \\
\hline Hindustan Petroleum & 7176 & 2974.94 & $42.47 \%$ & $-14.82 \%$ \\
\hline Bharath Petroleum & 8790 & 3211.44 & $36.53 \%$ & $-12.78 \%$ \\
\hline Indian Oil & 21417 & 9850.81 & $46.01 \%$ & $-13.22 \%$ \\
\hline
\end{tabular}

Table 1.3 shows the degree of consistency when it comes to the net profits of the companies. It is visible that IOC has the largest net profit amongst those three. The level of operations and number of refineries is one of the factors of more sales thus more profit. All the companies' net profit has been taken a toll of at least $(60 \%)$ less profit due to reduced sale being the reason of COVID-19 pandemic. The standard deviation of IOC is very high which shows the instability to make profits during the years. The profit CAGR is negative for all the three companies which shows that the profits are not rising for the past 5 years. 
Table 5.1.4 - Total Assets

\begin{tabular}{|c|c|c|c|c|}
\hline $\begin{array}{l}\text { Petroleum Companies } \\
\end{array}$ & $\begin{array}{l}\text { Total Assets } \\
\text { (Rs.) }\end{array}$ & $\begin{array}{l}\text { Standard } \\
\text { Deviation }\end{array}$ & $\begin{array}{l}\text { Coefficient } \\
\text { of Variation }\end{array}$ & CAGR (\%) \\
\hline Hindustan Petroleum & 90,702 & 17942.02 & $19.78 \%$ & $10.10 \%$ \\
\hline Bharath Petroleum & $1,02,041$ & 19777.99 & $19.38 \%$ & $10.72 \%$ \\
\hline Indian Oil & $2,77,451$ & 39311.48 & $14.17 \%$ & $7.12 \%$ \\
\hline
\end{tabular}

Total assets of Indian Oil corporation stood first due to its strong fundamentals and presence. But when it comes to the addition in asset for the past 5 years, the CAGR of HPCL \& BPCL is comparatively higher than IOC. It is a sign of growth for those two companies. But there is another school of thought which discusses about effective utilization of assets to generate profit. It is also another component of DuPont analysis. If table 1.1 is referred, asset turnover ratio of BPCL stood tad better than HPCL \& IOC which indicates more effective utilization of assets. The pandemic did not directly put a toll on the assets of these companies. They have not realized their assets into cash. There are more chances of a better Asset turnover ratio in the coming years as demand picks up.

\section{Findings \& Suggestions}

- The RoE gives a broader picture about the financial performance of the company for an investor to take investment decision

- Highest RoE is for BPCL is $1 \%$ more than its peers

- Higher the DuPont Ratio, better the company is good for long term investment

- COVID-19 has really taken a toll on sales and net profit for the petroleum companies as both of hem plummeted more than $60 \%$ in 2020

- The major causes of such reduction in sales is due to the lack of demand for fuel due to unprecedented and unexpected nationwide lockdown

- Industry PMI \& Manufacturing PMI also plummeted more than $77 \%$ in 2020 which clearly indicates dropping demand for fuel during the year

- The standard deviation effected all the companies when it comes to profitability \& sales. Over the last 4 years (2016-2019) all figures were more or less constant, but those changed rapidly in 2020 due to sudden change in profits $\&$ sales

- Total assets did not have an impact of the pandemic since the companies did not add or reduce it during the 5 years. Only a marginal change is visible and which is acceptable

- DuPont analysis is an effective tool to take investment decisions and provide the way of financial performance of a company using three metrics which are crucial in determining the profitability and efficiency of the business

\section{Conclusion}

In the study, the researcher had attempted to find out the effects of COVID-19 pandemic in the financial performance of three state-owned petroleum companies. The tool used in this study is DuPont analysis or RoE analysis. Return on Equity suggests whether the company is fair to invest or to skip investments. RoE is governed by three matrices 
namely Net profit ratio, Asset Turnover ratio \& Total assets to shareholders fund ratio. Unexpected ling term nationwide lockdowns, job loss, closing down industrial activities have really reduced the dispensable income of the retail consumers. The demand for fuel plummeted since March 2020 of more than $60 \%$ compared to four preceding years. This has taken toll not only on sale of fuel but also the overall profitability of the companies. The top performing company based on RoE is Bharath Petroleum as its RoE is the maximum compared to its peers. This study can be extended in the following years to come to study the impact of post COVID era in financial performance of these three companies.

\section{REFERENCES}

[1] Berghoff, C. and Kustner, C., n.d. Using DuPont Analysis to Predict Changes in Profitability.

[2] De Wet, J. and Du Toit, E., 2007. Return on equity: A popular, but flawed measure of corporate financial performance. South African Journal of Business Management, 38(1), pp.59-69.

[3] Doorasamy, M., 2016. Using DuPont analysis to assess the financial performance of the top 3 JSE listed companies in the food industry. Investment Management and Financial Innovations, 13(2), pp.29-44.

[4] Melvin, J., Boehlje, M., Dobbins, C. and Gray, A., 2004. The Dupont profitability analysis model: an application and evaluation of an e-learning tool. Agricultural Finance Review, 64(1), pp.75-89.

[5] Sarkar, R. and Choudhary, R., 2018. Impact of Capital Structure on Financial Performance: A Study of Select Automobile Companies in India. MUDRA: Journal of Finance and Accounting, 5(2).

[6] Soliman, M., 2007. The Use of Dupont Analysis by Market Participants. SSRN Electronic Journal. 